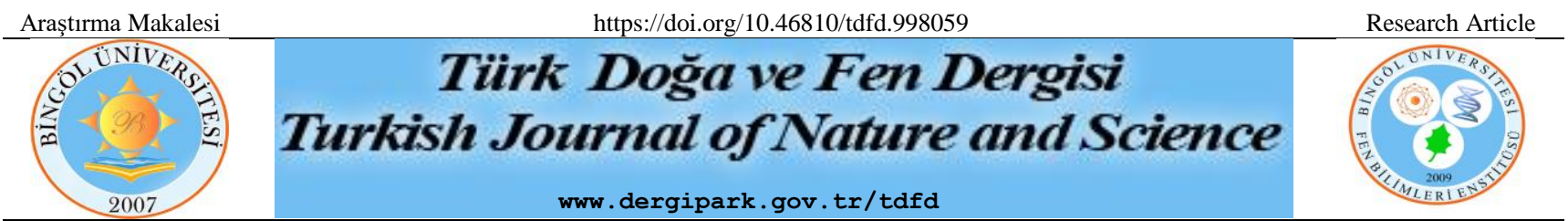

\title{
Melatonin Enhances the Chemosensitivity of Pancreatic Carcinoma Cells (PANC-1) to Cisplatin and Cetuximab through Modulation of p21, p27, p53, p57, MDM2, and KRAS Genes
}

\author{
Cihan GÜR ${ }^{1 *}$, Seçkin ÖZKANLAR ${ }^{1}$ \\ ${ }^{1}$ Atatürk Üniversitesi, Veteriner Fakültesi, Biyokimya Anabilim Dalı, Erzurum, Türkiye \\ Cihan GÜR ORCID No: 0000-0001-6775-7858 \\ Seçkin ÖZKANLAR ORCID No: 0000-0001-7717-797X \\ *Corresponding author: cihan.gur@atauni.edu.tr
}

(Alınış: 20.09.2021, Kabul: 09.11.2021, Online Yayınlanma: 31.12.2021)

\section{Keywords Cetuximab, Cisplatin, Melatonin, Oncogenes, Pancreatic Cancer, Tumor Suppressor Genes}

\begin{abstract}
In the present study, the effects on cell viability and some oncogenes and tumor suppressor genes were investigated after melatonin, cetuximab, and cisplatin were administered alone or in combination to the pancreatic ductal adenocarcinoma cell line (PANC-1). The cells were left for $48 \mathrm{~h}$ incubation after applying drugs on the PANC-1 cells. The metabolic effects of the substances on cell viability at the end of incubation were measured by MTT analysis. The gene expressions of p21, p27, p53, p57, MDM2, and KRAS were determined by RT-PCR. The use of melatonin combined with cisplatin or cetuximab increased p21 and p57 genes and decreased the KRAS gene. Furthermore, melatonin combined with cetuximab increased p27 gene expression and decreased cell viability compared to cetuximab alone. The cell viability was the lowest in cisplatin and cisplatin plus melatonin and/or cetuximab groups. The p53 were highest in the cisplatin groups while cisplatin plus melatonin decreased the p53 gene and its autoregulator MDM2 gene compared to cisplatin alone. In conclusion, melatonin in combination with cisplatin and cetuximab enhances the tumor suppressor genes p21, p27, and p57 along with a modulation of the oncogenic gene KRAS suggesting the potential of melatonin as a therapeutic approach in combination therapy of pancreatic ductal adenocarcinoma.
\end{abstract}

\section{Melatonin, p21, p27, p53, p57, MDM2 ve KRAS Genlerinin Modülasyonu Yoluyla Pankreas Karsinomu Hücrelerinin (PANC-1) Cisplatin ve Cetuximab'a Kemosensitivitesini Artırır}

\section{Anahtar \\ Kelimeler \\ Setuksimab, \\ Sisplatin, \\ Melatonin, \\ Onkogenler, \\ Pankreas \\ Kanseri, \\ Tümör \\ Baskılayıc1 \\ Genler}

Öz: Bu çalıșmada pankreatik duktal adenokarsinoma hücre hattına (PANC-1) melatonin, setuksimab ve sisplatin tek başına ya da kombine olarak uygulandıktan sonra hücre canlılığı ile birlikte bazı onkogenler ve tümör süpresör genler üzerine etkileri araştırıldı. PANC-1 hücrelerine ilaçlar uygulandıktan sonra hücreler 48 saat inkübasyona bırakıldı. İnkübasyon sonunda maddelerin hücre canlılığı üzerindeki metabolik etkileri MTT analizi ile ölçüldü. p21, p27, p53, p57, MDM2 ve KRAS'in gen ifadeleri RT-PCR ile belirlendi. Sisplatin veya setuksimab ile kombine melatonin kullanım1, p21 ve p57 genlerini arttırdı ve KRAS genini azalttı. Ayrıca, setuksimab ile kombine edilen melatonin, tek başına setuksimab ile karşılaştırıldığında p27 gen ekspresyonunu arttırdı ve hücre canlılığını azalttı. Hücre canlılığı, sisplatin ve sisplatin artı melatonin ve/veya setuksimab gruplarında en düşüktü. p53, sisplatin gruplarında en yüksek iken, sisplatin artı melatonin, tek başına sisplatine kıyasla p53 genini ve onun otoregülatör MDM2 genini azalttı. Sonuç olarak, sisplatin ve setuksimab ile kombinasyon halinde melatonin, tümör baskılayıc1 genler p21, p27 ve p57 ile birlikte onkojenik gen KRAS'ın bir modülasyonunu arttırır, bu da melatoninin pankreas duktal adenokarsinomunun kombinasyon tedavisinde terapötik bir yaklaşım olarak potansiyelini ortaya koyar.

\section{INTRODUCTION}

The incidence, prevalence, and mortality of pancreatic cancer increased during the last 25 years accounting for
$1.8 \%$ of all cancer types causing $4.6 \%$ of all cancer deaths with different demographic characteristics around the world [1]. Pancreatic ductal adenocarcinoma (PDAC) is the most aggressive and widely encountered type of all pancreatic tumors with an extremely poor 
prognosis and very low five-year survival rate [2]. The treatment is limited to chemotherapy for the majority of patients while the rich desmoplastic stroma of PDAC constitutes a physical barrier for anticancer therapy [3]. New information on genes and cellular progressions in pancreatic cancer provides the possibility for investigators to develop targeted/stromal therapies, immunotherapies, and combination chemotherapy [4] along with a better understanding of transcription dependence and DNA repair [5]. For example, a modified combination chemotherapy was found to be effective in the case of PDAC patients undergoing hemodialysis [6]. In a recent clinical trial, combination therapy over single-agent chemotherapy prolonged the overall survival in 239 elderly patients with metastatic PDAC [7]. Therefore, combination chemotherapy is one of the promising therapies to improve the volume and prognosis of this fatal malignancy.

Cisplatin, a potent inducer of cell death in cancer cells, is among the most effective and widely used chemotherapeutic [8]. Cisplatin is known to inhibit DNA repair by forming cross-links in DNA and moving cells in the apoptotic pathway [9]. Although cisplatin has significant cytotoxic effects against pancreatic cancer cells, the underlying mechanisms are still not fully understood. However, it has been reported that the anticancer effect of cisplatin may be related to p53 activation [10]. The cisplatin and gemcitabine combination therapy significantly prolonged survival over monotherapy in metastatic pancreatic cancer [11]. Cetuximab is an immunoglobulin G1 chimeric mousehuman monoclonal antibody and has a high affinity for the epidermal growth factor receptor (EGFR) [12]. Many proapoptotic pathways are activated in the cell when it bounds to EGFR [13].

Melatonin hormone synthesized from tryptophan and secreted from the pineal gland is a powerful free radical scavenger with antioxidant and anti-tumor properties in pancreatic cancer [14]. The anti-cancer mechanism of melatonin occurs through anti-oxidant activation against stress, inhibition of proliferation, and induction of apoptosis [15]. The use of melatonin caused apoptosis in the hepatocarcinoma HepG2 cell line without showing any significant side effects [16]. Melatonin enhanced the chemosensitivity of gemcitabine through the modulation of the apoptotic pathway in PANC-1 cells [17]. However, the effects of the combined use of melatonin have partly been studied through tumor suppressor or oncogenic genes in pancreatic cancer cells. In this study, it was therefore aimed to investigate the effects of cisplatin, cetuximab, and melatonin alone or in combination on tumor suppressor genes of p21, p27, p53, and p57, and oncogenic genes of MDM2 and KRAS expressions in PANC-1 cell line.

\section{MATERIAL AND METHODS}

\subsection{Chemicals}

Cisplatin was obtained from Koçak Farma (50 mg/100 $\mathrm{ml}$, Turkey) and cetuximab from Merk (2 mg/ml,
Germany). Melatonin, ethanol, fetal bovine serum (FBS), dimethylsulfoxide (DMSO), L-glutamine, phosphate buffer saline (PBS) 3-[4,5-dimethylthiazol-2yl]-2,5-diphenyltetrazolium bromide (MTT) analysis kits were purchased from Sigma-Aldrich (St. Louis, MO, USA). The mRNA isolation kit, cDNA synthesis kit, ACTB, p21, p27, p53, p57, MDM2 and KRAS primers were purchased from Qiagen (USA). Dulbecco's Modified Eagle Medium (DMEM) was obtained from Bio-AMF-1 (Israel) and Penicillin + Streptomycin from Gibco (USA)

\subsection{Cells}

The PANC-1 cell line was obtained from Atatürk University Faculty of Medicine, Department of Pharmacology and Toxicology in passage 6. Atatürk University Faculty of Medicine, Department of Pharmacology and Toxicology had obtained these cells from the American Type Culture Collection (ATCC ${ }^{\circledR}$ CRL-1469 TM). Cells were stored at $-196{ }^{\circ} \mathrm{C}$ in liquid nitrogen. The properties of the cells are presented in Table 1.

Table 1. Cell Properties

\begin{tabular}{cc}
\hline Category & Properties \\
\hline Organism & Human \\
Gender & Male \\
Age & 56 \\
Tissue & Pancreas duct \\
Surface adhesion & Adhesive cells \\
Product Format & Frozen \\
\hline
\end{tabular}

\subsection{Cell Culture}

Cells were reproduced in Dulbecco's Modified Eagle Medium (DMEM, Life Technologies, USA) containing $10 \%$ FBS, $100 \mathrm{U} / \mathrm{ml}$ penicillin and $100 \mu \mathrm{g} / \mathrm{ml}$ streptomycin in an incubator set at $37^{\circ} \mathrm{C}$ with $5 \%$ carbon dioxide $(\mathrm{CO} 2)$ and $95 \%$ humidity within $25 \mathrm{~cm} 2$ flasks under sterile conditions.

\subsection{Cell Viability Assay}

The MTT (3-(4,5-dimethylthiazol-2-yl)-2,5diphenyltetrazolium bromide) assay was used for the estimation of the metabolic activity of living cells to determine cytotoxicity. 5000 cells in $100 \mu$ l culture medium were inoculated into each well of the 96-well plate one day before the analysis. Then the plates were left to incubate for $24 \mathrm{~h}$ in an incubator with $5 \% \mathrm{CO} 2$ and $37{ }^{\circ} \mathrm{C}$. At the end of the $24 \mathrm{~h}$ incubation of the cells, cisplatin, cetuximab and melatonin prepared in certain concentrations were applied into the medium in the wells by sterile automatic pipettes. One of the groups was separated as a cell control group. The groups were divided into Melatonin (MEL), Cisplatin (CIS), Cetuximab (CET), MEL-CIS, MEL-CET, CIS-CET and MEL-CIS-CET. After the application of the substances, the cells were left to incubate for $48 \mathrm{~h}$ in the incubator with $5 \% \mathrm{CO} 2$ and $37{ }^{\circ} \mathrm{C}$. The MTT analysis was started at the end of the incubation periods. The medium was incubated for $4 \mathrm{~h}$ after adding thiazolyl tetrazolium bromide solution to the cell content. DMSO was added 
onto the medium-cell-thiazolyl tetrazolium bromide solution mixture and left to incubate again for 20 minutes. After the incubation, the plates were read at 570 $\mathrm{nm}$ in an ELISA device.

In order to calculate the cell viability percentage, the absorbance values obtained from the MTT analysis in which melatonin, cisplatin, cetuximab and their combinations were divided by the absorbance value of the control group and multiplied by 100 as shown below.

$\%$ Cell Viability $=($ Drug Administration Absorbance Value) / (Control Group Absorbance Value) X 100

The effective doses were calculated as $10 \mathrm{nM}$ for melatonin [Figure 1A], $100 \mathrm{nM}$ for cetuximab (Figure $1 \mathrm{~B}$ ) and $50 \mu \mathrm{M}$ for cisplatin (Figure 1C).

\subsection{Total RNA Isolation and cDNA Synthesis}

Total RNA isolation from cells obtained from flasks with different combinations of drug applications was performed using the methods specified by the manufacturer of a commercial kit (RNeasy Mini Kit, Qiagen). For cDNA synthesis from the obtained total RNA, it was performed with the QuantiTect Reverse Transcription Kit according to the manufacturer's instructions. Primers readily available from Qiagen were used in the Real-Time PCR analysis. RefSeq and catalogue numbers of primers are given in Table 2 . Relative folds of expressions were assessed with the 2 $\triangle \Delta \mathrm{CT}$ method.

Table 2. RefSeq and catalogue numbers of primers

\begin{tabular}{ccc}
\hline Gene & RefSeq Numbers & Catalogue Numbers \\
& & \\
\hline p53 & NM_000546 & QT00060235 \\
MDM2 & NM_002392 & QT00056378 \\
p21 & NM_000389 & QT00062090 \\
p27 & NM_004064 & QT00998445 \\
p57 & NM_000076 & QT00018018 \\
KRAS & NM_004985 & QT00083622 \\
ACTB & NM_001101 & QT00095431 \\
\hline
\end{tabular}

\subsection{Statistical Analyses}

Statistical analysis was performed between the groups by One-Way ANOVA with Duncan's post hoc test after determining a homogeneous distribution. A value of $\mathrm{p}<0.05$ was considered statistically significant.

\section{RESULTS}

\subsection{Cell Viability}

The cell viability rates were the lowest in CIS, MELCIS, MEL-CET, CIS-CET, and MEL-CIS-CET groups as compared to the Control group which was accepted as $100 \%$ alive $(\mathrm{P}<0.05)$ after $48 \mathrm{~h}$ of incubation. The decrease in cell viabilities in these groups was in a similar manner without having any difference among each other. A statistical decrease was also observed in cell viability of the MEL group compared to the Control group while the rate was higher than the other groups
$(\mathrm{P}<0.05)$. The CET group was lower than MEL and Control group and higher than the CIS and combination groups $(\mathrm{P}<0.05)$. Additionally, the cell viability of MELCET groups was statistically lower than the CET group $(\mathrm{P}<0.05)$. The percentage viability rates of the MTT analyses are presented in Figure 1D.
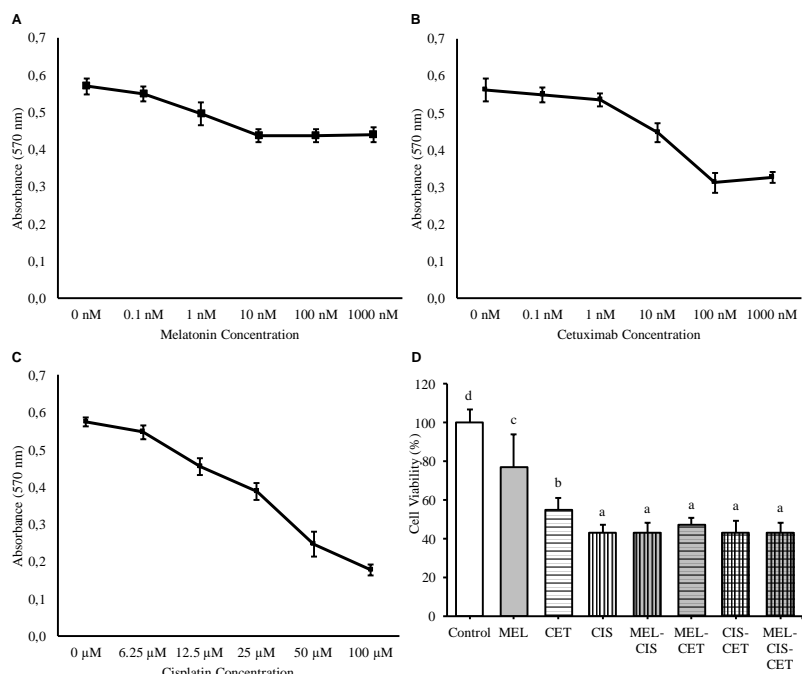

Figure 1. The absorbances of melatonin (A), cetuximab (B) and cisplatin (C) in MTT analysis (3-(4,5-dimethylthiazol-2-yl)-2,5diphenyltetrazolium bromide). The plates were read at $570 \mathrm{~nm}$ in an ELISA device. Cell viability percentages of PANC-1 cells in groups after $48 \mathrm{~h}$ incubation (D). Different letters represent statistical difference at the significance of $p<0.05$ at least; same letters do not represent a statistical difference $(\mathrm{p}>0.05)$ among groups. The bars represent mean $\pm \mathrm{SD}$.

\section{2. p53, MDM2, p21, p27, p57 and KRAS Gene Expression Levels}

The group with the highest p53 mRNA transcript level was the CIS group $(\mathrm{P}<0.05)$. The highest expression levels after the CIS group were in MEL-CIS-CET, CISCET, and MEL-CIS groups $(\mathrm{P}<0.05)$, respectively, and there was no difference between the p53 expressions of CIS-CET and MEL-CIS groups. The p53 gene expression levels decreased in MEL-CIS and MEL-CET compared to CIS and CET groups, respectively ( $\mathrm{P}<0.05)$. There were increases in MEL and CET groups, but these increases were found to be less than the other groups. The lowest p53 gene expression levels were found in the MEL-CET group. The p53 gene expression levels in the groups are presented in Figure 2A.

The MDM2 expression levels in all groups were higher than in the Control group $(\mathrm{P}<0.05)$. The highest increase in MDM2 level was found in the CIS group compared to the Control and the other groups $(\mathrm{P}<0.05)$. It was determined that the highest increase after the CIS group was in the MEL-CIS, CIS-CET, and MEL-CIS-CET groups, respectively. The increases in MEL, CET, and MEL-CET groups were lower than the remaining groups while the levels were still higher than the Control group. The MDM2 gene expression levels in the groups are presented in Figure 2B.

The highest expression levels according to the p21 gene expression levels were in the MEL-CIS, CIS, CIS-CET, and MEL-CIS-CET groups $(\mathrm{P}<0.05)$. There was no 
difference between CIS and MEL-CIS-CET groups and between CIS-CET and MEL-CIS-CET groups. The increases in MEL, CET and MEL-CET groups were lower than the remaining groups while the levels were still higher than the Control group. The p21 gene expression levels in the groups are presented in Figure $2 \mathrm{C}$.

There were decreases in the p27 gene expression level in all groups compared to the control group $(\mathrm{P}<0.05)$ except for the MEL-CET group. There was also a significant increase in p27 gene expression in the MELCET group compared to the CET group $(\mathrm{P}<0.05)$. The greatest decrease among the groups occurred in the MEL-CIS-CET group. The p27 gene expression levels in the groups are presented in Figure 2D.

The increases in p57 gene expressions were significantly higher in combination groups of MEL-CIS, CIS-CET,
MEL-CIS-CET and MEL-CET than single drug groups of MEL, CET, and CIS $(\mathrm{P}<0.05)$. The levels in CET and CIS groups were also higher than the Control group $(\mathrm{P}<0.05)$ while the level in the MEL group was not different from the Control group. The p57 gene expression levels in the groups are presented in Figure $2 \mathrm{E}$.

Significant increases in the KRAS gene expression were observed in CIS, MEL-CIS, and MEL-CIS-CET groups compared to the Control group $(\mathrm{P}<0.05)$. However, the KRAS gene expression decreased in MEL and MELCET groups in the same manner as compared to the Control group $(\mathrm{P}<0.05)$. There was no difference between the CIS-CET group and the Control group. The KRAS gene expression levels in the groups are presented in Figure $2 \mathrm{~F}$.
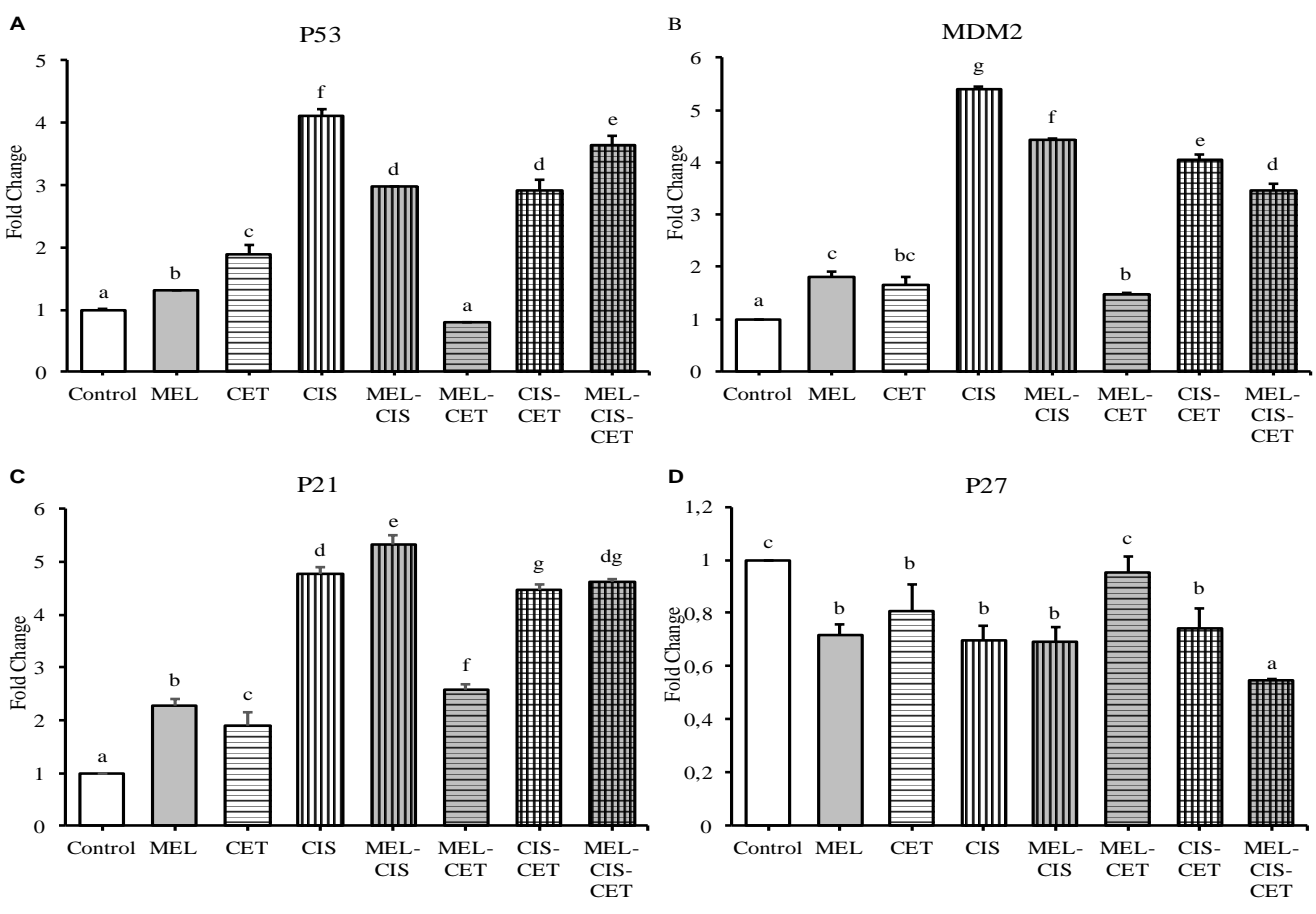

D

P27
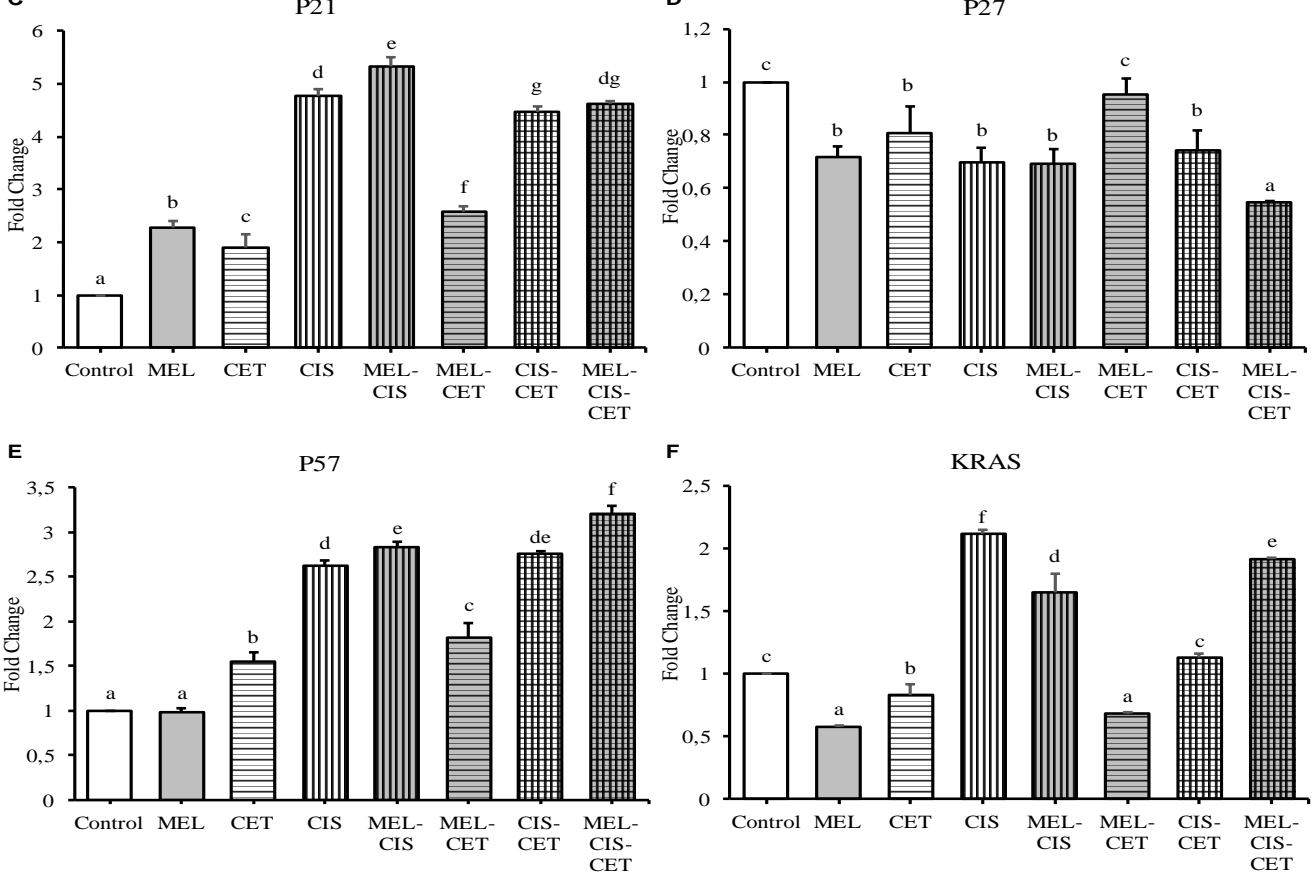

Figure 2. Gene expression levels of p53 (A), MDM2 (B), p21 (C), p27 (D), p57 (E) and KRAS (F) of PANC-1 cell lines in all groups at the end of 48 $\mathrm{h}$ of incubation. Different letters represent statistical difference at the significance of $\mathrm{p}<0.05$ at least; same letters do not represent a statistical difference $(\mathrm{p}>0.05)$ among groups. The bars represent mean \pm SD

\section{DISCUSSION}

In this study, we showed the synergistic effects of melatonin combined with cisplatin and cetuximab treatments on tumor suppressor genes and oncogenes in the PANC-1 cell lines of PDAC carcinogenesis. Pancreatic cancer has a poor prognosis and is still among the most fatal malignancies despite all efforts to develop effective therapy [18]. The main challenge in the treatment of pancreatic cancer is the recurrence 
within 1-2 years and/or the development of hepatic metastases. Surgical procedures do not substantially improve the survival rate alone in pancreatic cancer treatment [19]. The majority of patients are dying from drug-resistant or metastatic disease accounting for less than $10 \%$ five-year survival rate. Current preclinical and clinical efforts are focused on the development of effective combination therapy for pancreatic cancer [5].

Drug resistance including cisplatin is a challenge in pancreatic cancer treatment $[11,20]$. The synergistic and antagonistic interactions of drugs in combination should enhance the extent of apoptosis and reduce toxicity. We found that melatonin decreased PANC-1 cell viability and melatonin combinations with cisplatin and cetuximab were more prominent in the cell viabilities. Cetuximab treatment reduced the cell viability in HepG2 cells by up to $50 \%$ in hepatocellular carcinoma cell lines treated with cetuximab alone or in combination with NSC 74859 [21]. Co-administration of melatonin in combination with chemotherapeutic drugs including cisplatin is a powerful synergistic agent through the intracellular reactive oxygen species in AR42J tumor cells derived from a rat exocrine pancreas [22]. Furthermore, melatonin improves the anticancer activity of sorafenib through the melatonin receptor and PDGFR- $\beta$ /STAT3 signaling pathway in PDAC [23] and enhances the chemosensitivity to gemcitabine through the modulation of the apoptotic pathway in PANC-1 cells [17]. Our findings suggest that cisplatin in combination with melatonin and/or cetuximab is as effective to reduce the cell viability as cisplatin alone. Surprisingly, the cetuximab in combination with melatonin decreased the cell viability more than cetuximab alone. Cetuximab inhibits epidermal growth factor receptors, and cisplatin causes severe damage to DNA leading to apoptosis of cells and reducing cell viability while melatonin may have protective effects against drug-induced cytotoxicity.

The main role of the tumor suppressor gene p53 in cancer is to keep the cell cycle in the G1/S phase [24]. However, inactivation of the p53 gene is common in pancreatic carcinoma and is found in approximately 50$70 \%$ of pancreatic cancer cases [25]. In the present study, melatonin treatment alone activated p53 expression compared to the control group and p53 activity was highest in the cisplatin treatment groups. T4 suppressed mRNA expressions of pro-apoptotic genes p53 and RRM2B might be significantly increased with the combination of Nano-Diamino-Tetrac and cetuximab [26]. The administration of melatonin to human gastric cancer cells reduces MDM2, phosphoMDM2, AKT, and phospho-AKT proteins and consequently increases p53 expression indicating the oncostatic effects of melatonin [27]. When melatonin was applied to MDA-MB-231, the line of breast cancer cells, an increase was observed in p53 protein expression [28]. We determined that the $\mathrm{p} 53$ expression was the highest in PANC-1 cells indicating the effectiveness of cisplatin. However, when melatonin was administered together with cisplatin, it was observed that p53 expression decreased. Due to the antioxidant properties of melatonin, it is thought that the DNA damage caused by cisplatin is reduced and accordingly it causes a decrease in p53 expression.

Approximately $50 \%$ of the mutation in the p53 gene has been reported in the various genetic changes in pancreatic cancer. In the remaining 50\%, MDM2 inhibits the function by causing the ubiquitination and proteasomal-dependent degradation of p53 although the p53 gene continues to function normally [29]. Treatments based on regulating the function of p53 by blocking MDM2 using small molecule inhibitors have been found to be effective in inducing apoptosis and stopping growth by activating the wild-type p53 pathway [30]. We found that the highest MDM2 expression was in the group treated with cisplatin alone at the end of $48 \mathrm{~h}$ of incubation. Although there was an increase in the group treated with melatonin alone compared to the control group, this was less than the cisplatin group. Additionally, the administration of melatonin to MCF-7 cells was reported to suppress MDM2 expression [31]. The p53/MDM2 ratio increases significantly when applied vitamin D3 with melatonin to MCF-7 cells [32]. It was determined that the expressions of MDM2 and p53 gene levels increased in correlation with each other in the groups suggesting that MDM2 gene is expressed to autoregulate the p53 gene in PANC-1 cells.

The p21 gene is a cell-cycle inhibitor controlled by the p53 gene and independent pathways of the p53 gene [33]. We showed that the p21 expression is higher in combination with melatonin than cisplatin or cetuximab alone. The combinations of docetaxel and cisplatinloaded liquid crystalline nanoparticles with folic acid enhanced the apoptotic markers of Bax, p21, and ccaspase 3 resulted in anti-cancer effects to metastatic breast cancer [34]. Furthermore, the combination of hydroxytyrosol and cetuximab significantly increases the p21 gene expression in colon cancer cells [35]. Administration of melatonin alone to breast cancer cells MCF-7 decreased p21 and p53 levels compared to the control group while the combination of melatonin with arsenic trioxide increased p21 and p53 levels compared to arsenic trioxide alone [36]. Consistent with previous reports, our findings show that cisplatin administration with melatonin combination increases p21 expression level and causes PANC-1 cells to be involved in the G1/S phase, thereby causing a decrease in cell viability. The decrease in p27 expression has been correlated with high tumor grade and advanced stage in pancreatic cancer [37]. The p53 gene targets its downstream gene, p21, to block the cell cycle. When the p53/p21 signaling pathway is activated, the cell cycle is arrested in G0/G1 phase [38]. We found that P27 expression levels decreased in all groups except for cetuximab combined with melatonin, whereas there was no difference compared to the control group. In a previous study, the use of cisplatin and bithionol alone increased both p27 and p21 expressions while cisplatin combined with bithionol decreased these levels in the cisplatin-sensitive cell lines [A2780 and IGROV-1] and increased in the cisplatin-resistant cell lines [A2780-CDDP and 
IGROV1-CDDP] [39]. We determined that cisplatin, cetuximab, and melatonin increased the p21 expression levels and decreased the p27 expression levels in the PANC-1 cell lines.

The p57 gene is suggested to be a tumor suppressor gene that acts as downregulation of cell proliferation. The P57-mediated autophagy promotes the efficacy of EGFR [epidermal growth factor receptor] inhibitors. Upregulation of p57 decreases the level of autophagy and enhances the decrease in cell viability in hepatocellular carcinoma [40]. In addition, p57 expression makes cancer cells more sensitive to cisplatin. Silencing of the p57 gene has been reported to suppress cisplatin-induced apoptosis in several cell lines [41]. We found significant increases in the p57 expression levels in melatonin combined with cisplatin and cetuximab compared to single drug groups. The increase in p57 expression makes PANC-1 cells more susceptible to both cetuximab and cisplatin, causing autophagy and apoptosis and leading to a decrease in cell viability by inhibiting the cell cycle in the G1/S phase.

Activating mutations of the KRAS gene are found in most of the PDAC cases and occur during the early stages of malignant transformation to promote tumorigenesis [42]. Activation of KRAS signaling causes cell growth and differentiation. Potent regulators of KRAS oncogene have been targeted to provide a therapeutic strategy for the treatment of pancreatic cancer. The KRAS signaling pathway is pivotal for PDAC development. The mutations cause persistent KRAS activation, loss of differentiation, accelerated proliferation, and prolonged survival. In a recent study, downregulation of KRAS pathway expression has been used for a putative biomarker for prediction of drug activity and for stimulation of anticancer effects in various PDAC models [43]. Furthermore, we found that melatonin combined with cisplatin and cetuximab decreased KRAS gene expression compared to the single-use of cisplatin or cetuximab in the PANC-1 cells. These data suggest that Melatonin may prevent differentiation and/or accelerated proliferation by reducing KRAS expression and by inhibiting the cell cycle of cancer cells through suppressing cyclin D. The KRAS expression, as a putative biomarker, is correlated with p57 and p21 gene expressions.

\section{CONCLUSION}

In conclusion, the alive cell densities in cell viability percentage were the lowest in cisplatin and cisplatin plus melatonin and/or cetuximab groups. The tumor suppressor gene p53 was highest in the cisplatin groups while cisplatin plus melatonin decreased the p53 gene and its autoregulator MDM2 gene compared to cisplatin alone. It was further determined that melatonin administration to PANC-1 cells did not cause negative effect on the efficacy of cisplatin; besides, the combination of melatonin with cisplatin and cetuximab increased the expression of tumor suppressor genes p21, p27, and p57. Surprisingly, melatonin in combination decreased the oncogenic gene KRAS suggesting the potential of melatonin as a therapeutic approach in combination therapy of pancreatic ductal cell carcinoma. Further in vivo and in vitro molecular studies of the application of melatonin combined with chemotherapeutics including cisplatin and cetuximab are needed.

\section{Acknowledgement}

This study was supported by Ataturk University, Foundation of Scientific Researches Projects [Project number: PRJ2014/154].

\section{REFERENCES}

[1] Lippi G, Mattiuzzi C. The global burden of pancreatic cancer. Arch Med Sci. 2020;16(4):8204.

[2] Kong F, Liu X, Zhou Y, Hou X, He J, Li Q, et al. Downregulation of METTL14 increases apoptosis and autophagy induced by cisplatin in pancreatic cancer cells. The International Journal of Biochemistry \& Cell Biology. 2020;122:105731.

[3] Han H, Hou Y, Chen X, Zhang P, Kang M, Jin Q, et al. Metformin-Induced Stromal Depletion to Enhance the Penetration of Gemcitabine-Loaded Magnetic Nanoparticles for Pancreatic Cancer Targeted Therapy. Journal of the American Chemical Society. 2020;142(10):4944-54

[4] Chandana S, Babiker HM, Mahadevan D. Therapeutic trends in pancreatic ductal adenocarcinoma (PDAC). Expert Opin Investig Drugs. 2019;28(2):161-77.

[5] Miller AL, Garcia PL, Yoon KJ. Developing effective combination therapy for pancreatic cancer: An overview. Pharmacol Res. 2020;155:104740.

[6] Kaneko T, Sugimori K, Tozuka Y, Fukushima T, Okada K, Oka H, et al. Combination chemotherapy with gemcitabine and nab-paclitaxel for a metastatic pancreatic ductal adenocarcinoma patient undergoing hemodialysis. Clin J Gastroenterol. 2019;12(5):484-9.

[7] Xie H, Liu J, Ogden JR, Yin J, Jatoi A, Hubbard JM, et al. Survival Benefit of Combination Chemotherapy in Elderly Patients With Metastatic Pancreatic Ductal Adenocarcinoma. Am J Clin Oncol. 2020;43(8):586-90.

[8] Chen B, Xu M, Zhang H, Wang J-x, Zheng P, Gong L, et al. Cisplatin-induced non-apoptotic death of pancreatic cancer cells requires mitochondrial cyclophilin-D-p53 signaling. Biochemical and biophysical research communications. 2013;437(4):526-31.

[9] Ergun Y, Ozdemir NY, Guner EK, Esin E, Sendur MA, Koksoy EB, et al. Comparison of gemcitabine monotherapy with gemcitabine and cisplatin combination in metastatic pancreatic cancer: a retrospective analysis. J BUON. 2018;23:116-21.

[10] Bragado P, Armesilla A, Silva A, Porras A. Apoptosis by cisplatin requires p53 mediated p $38 \alpha$ 
MAPK activation through ROS generation. Apoptosis. 2007;12(9):1733-42.

[11] Yin F, Zhang Q, Dong Z, Hu J, Ma Z. LncRNA HOTTIP Participates in Cisplatin Resistance of Tumor Cells by Regulating miR-137 Expression in Pancreatic Cancer. OncoTargets and therapy. 2020;13:2689.

[12] Jimeno A, Rubio-Viqueira B, Amador ML, Oppenheimer D, Bouraoud N, Kulesza P, et al. Epidermal growth factor receptor dynamics influences response to epidermal growth factor receptor targeted agents. Cancer research. 2005;65(8):3003-10.

[13] Cheng Y-d, Yang H, Chen G-q, Zhang Z-c. Molecularly targeted drugs for metastatic colorectal cancer. Drug design, development and therapy. 2013;7:1315.

[14] Ruiz-Rabelo J, Vázquez R, Arjona Á, Perea D, Montilla $\mathrm{P}$, Túnez $\mathrm{I}$, et al. Improvement of capecitabine antitumoral activity by melatonin in pancreatic cancer. Pancreas. 2011;40(3):410-4.

[15] Li W, Wu J, Li Z, Zhou Z, Zheng C, Lin L, et al. Melatonin induces cell apoptosis in Mia PaCa-2 cells via the suppression of nuclear factor- $\kappa \mathrm{B}$ and activation of ERK and JNK: A novel therapeutic implication for pancreatic cancer. Oncology reports. 2016;36(5):2861-7.

[16] Martín-Renedo J, Mauriz JL, Jorquera F, RuizAndrés O, González $\mathrm{P}$, González-Gallego J. Melatonin induces cell cycle arrest and apoptosis in hepatocarcinoma HepG2 cell line. Journal of pineal research. 2008;45(4):532-40.

[17] Leja-Szpak A, Nawrot-Porabka K, Goralska M, Jastrzebska M, Link-Lenczowski P, Bonior J, et al. Melatonin and its metabolite N1-acetyl-N2formyl-5-methoxykynuramine (afmk) enhance chemosensitivity to gemcitabine in pancreatic carcinoma cells (PANC-1). Pharmacol Rep. 2018;70(6):1079-88.

[18] Kamisawa T, Wood LD, Itoi T, Takaori K. Pancreatic cancer. The Lancet. 2016;388(10039):73-85.

[19] Neoptolemos J, Dunn J, Stocken D, Almond J, Link $\mathrm{K}$, Beger $\mathrm{H}$, et al. Adjuvant chemoradiotherapy and chemotherapy in resectable pancreatic cancer: a randomised controlled trial. The Lancet. 2001;358(9293):157685.

[20] Mezencev R, Matyunina LV, Wagner GT, McDonald JF. Acquired resistance of pancreatic cancer cells to cisplatin is multifactorial with cell context-dependent involvement of resistance genes. Cancer Gene Ther. 2016;23(12):446-53.

[21] Chen W, Shen X, Xia X, Xu G, Ma T, Bai X, et al. NSC 74859-mediated inhibition of STAT 3 enhances the anti-proliferative activity of cetuximab in hepatocellular carcinoma. Liver International. 2012;32(1):70-7.

[22] Uguz AC, Cig B, Espino J, Bejarano I, Naziroglu $\mathrm{M}$, Rodríguez $\mathrm{AB}$, et al. Melatonin potentiates chemotherapy-induced cytotoxicity and apoptosis in rat pancreatic tumor cells. Journal of pineal research. 2012;53(1):91-8.
[23] Fang Z, Jung KH, Yan HH, Kim SJ, Rumman M, Park JH, et al. Melatonin Synergizes with Sorafenib to Suppress Pancreatic Cancer via Melatonin Receptor and PDGFR-beta/STAT3 Pathway. Cell Physiol Biochem. 2018;47(5):175168.

[24] Geske F, Nelson AC, Lieberman R, Strange R, Sun T, Gerschenson L. DNA repair is activated in early stages of p53-induced apoptosis. Cell Death \& Differentiation. 2000;7(4):393-401.

[25] Slebos RJ, Hoppin JA, Tolbert PE, Holly EA, Brock JW, Zhang RH, et al. K-ras and p53 in pancreatic cancer: association with medical history, histopathology, and environmental exposures in a population-based study. Cancer Epidemiology and Prevention Biomarkers. 2000;9(11):1223-32.

[26] Lee Y-S, Chin Y-T, Yang Y-CS, Wei P-L, Wu H$\mathrm{C}$, Shih A, et al. The combination of tetraiodothyroacetic acid and cetuximab inhibits cell proliferation in colorectal cancers with different K-ras status. Steroids. 2016;111:63-70.

[27] Song J, Ma S-J, Luo J-H, Zhang H, Wang R-X, Liu $\mathrm{H}$, et al. Melatonin induces the apoptosis and inhibits the proliferation of human gastric cancer cells via blockade of the AKT/MDM2 pathway. Oncology reports. 2018;39(4):1975-83.

[28] Gelaleti GB, Borin TF, Maschio-Signorini LB, Moschetta MG, Jardim-Perassi BV, Calvinho GB, et al. Efficacy of melatonin, IL-25 and silL-17B in tumorigenesis-associated properties of breast cancer cell lines. Life sciences. 2017;183:98-109.

[29] Chi S-W, Lee S-H, Kim D-H, Ahn M-J, Kim J-S, Woo J-Y, et al. Structural details on mdm2-p53 interaction. Journal of Biological Chemistry. 2005;280(46):38795-802.

[30] Azmi AS, Aboukameel A, Banerjee S, Wang Z, Mohammad M, Wu J, et al. MDM2 inhibitor MI319 in combination with cisplatin is an effective treatment for pancreatic cancer independent of p53 function. European Journal of Cancer. 2010;46(6):1122-31.

[31] Proietti S, Cucina A, Dobrowolny G, D'Anselmi F, Dinicola S, Masiello MG, et al. Melatonin downregulates MDM 2 gene expression and enhances p53 acetylation in MCF-7 cells. Journal of pineal research. 2014;57(1):120-9.

[32] Proietti S, Cucina A, D’Anselmi F, Dinicola S, Pasqualato A, Lisi E, et al. Melatonin and vitamin D3 synergistically down-regulate Akt and MDM2 leading to TGF $\beta$-1-dependent growth inhibition of breast cancer cells. Journal of pineal research. 2011;50(2):150-8.

[33] El-Deiry WS. p21 [WAF1] mediates cell-cycle inhibition, relevant to cancer suppression and therapy. Cancer research. 2016;76(18):5189-91.

[34] Thapa RK, Choi JY, Gupta B, Ramasamy T, Poudel BK, Ku SK, et al. Liquid crystalline nanoparticles encapsulating cisplatin and docetaxel combination for targeted therapy of breast cancer. Biomaterials science. 2016;4(9):1340-50.

[35] Terzuoli E, Nannelli G, Frosini M, Giachetti A, Ziche M, Donnini S. Inhibition of cell cycle 
progression by the hydroxytyrosol-cetuximab combination yields enhanced chemotherapeutic efficacy in colon cancer cells. Oncotarget. 2017;8(47):83207.

[36] Nooshinfar E, Bashash D, Safaroghli-Azar A, Bayati S, Rezaei-Tavirani M, Ghaffari SH, et al. Melatonin promotes ATO-induced apoptosis in MCF-7 cells: Proposing novel therapeutic potential for breast cancer. Biomedicine \& Pharmacotherapy. 2016;83:456-65.

[37] Juuti A, Nordling S, Louhimo J, Lundin J, Von Boguslawski K, Haglund C. Loss of p27 expression is associated with poor prognosis in stage I-II pancreatic cancer. Oncology. 2003;65(4):371-7.

[38] Zhu F, Dai SN, Xu DL, Hou CQ, Liu TT, Chen $\mathrm{QY}$, et al. EFNB2 facilitates cell proliferation, migration, and invasion in pancreatic ductal adenocarcinoma via the $\mathrm{p} 53 / \mathrm{p} 21$ pathway and EMT. Biomed Pharmacother. 2020;125:109972.

[39] Ayyagari VN, Hsieh T-hJ, Diaz-Sylvester PL, Brard L. Evaluation of the cytotoxicity of the Bithionol-cisplatin combination in a panel of human ovarian cancer cell lines. BMC cancer. 2017;17(1):49.

[40] Li WY, Li Q, Jing L, Wu T, Han LL, Wang Y, et al. P57-mediated autophagy promotes the efficacy of EGFR inhibitors in hepatocellular carcinoma. Liver International. 2019;39(1):147-57.

[41] Guo H, Tian T, Nan K, Wang W. p57: A multifunctional protein in cancer. International journal of oncology. 2010;36(6):1321-9.

[42] Lanfredini S, Thapa A, O'Neill E. RAS in pancreatic cancer. Biochem Soc Trans. 2019;47(4):961-72.

[43] Oliverius M, Flasarova D, MohelnikovaDuchonova B, Ehrlichova M, Hlavac V, Kocik M, et al. KRAS pathway expression changes in pancreatic cancer models by conventional and experimental taxanes. Mutagenesis. 2019;34(56):403-11. 